\title{
EFFECTS OF THE WALNUT INCLUSION IN THE DIET OF IN THE YOUNG MALE PATIENTS OF ESSENTIAL HYPERTENSION ON LIPID PROFILE, BLOOD PRESSURE.
}

Gullapalli H. S, Avinash P. Tekade, Namrata Gullapalli.

1. Associate Professor. Department of Physiology, Vinayaka Mission Medical College, Karaikal, Puducherry.

2. Associate Professor. Department of Physiology, Katuri Medical College and Hospital, Guntur, Andhra Pradesh.

3. Lecturer cum Dietitian and Nutritionist. Vinayaka Mission Medical College, Karaikal, Puducherry.

\section{CORRESPONDING AUTHOR}

Dr. Gullapalli H. S,

F-1, VMMCH Staff Quarters,

Kottucherry, Karaikal.

E-mail: hgullapalli2000@gmail.com

Ph: 00918903318772.

ABSTRACT: Aim of the present study to assess the effect of inclusion of walnut in the diet of male patients of Stage I essential hypertension without secondary complication, on lipid profile, blood pressure and anthropometry. 27 patient of stage I essential hypertensive where given 4 weeks of control diet which includes uniform local diet. Later on for six weeks the control diet is changed to include walnut which represents $33 \%$ of energy supplied from fat and other fat sources were reduced to accommodate walnut in the study diet. This resulted in the favorable change in the lipid profile due to walnut diet like statistically significant decrease in the total cholesterol, triglycerides, LDL-cholesterol and HDL/LDL ratio (P value $<0.001$ ) and significant increase in HDL-cholesterol; , statistically significant reduction in the systolic and diastolic blood pressure (P value $<0.001$ ) as compared to control diet.

KEYWORDS: Walnut, Lipid Profile, blood pressure, diet, cholesterol.

INTRODUCTION: Among naturally occurring foods, walnuts are one of the highest sources of the n-3 fatty acid alpha-linolenic acid; they contain approximately 9 gm of alpha-linolenic acid per $100 \mathrm{~g}$ of edible matter ${ }^{1}$. Some studies of dietary intervention with walnut in the humans shows beneficial effect on serum lipid profile and blood pressure $2,3,4,5,6$. Inclusion of walnut in the diet increases the polyunsaturated to saturated fatty acid ratio (P: S) which has been reported to reduce blood pressure in humans to a significant extent ${ }^{7}$.

In a controlled feeding trial by Sabaté and colleagues ${ }^{3}$, a diet in which walnuts represented $55 \%$ of the energy from fat reduced blood cholesterol levels in normalyoung men when compared with a standard low-fat diet.

MATERIALS AND METHOD: This study is conducted in the Department of Food and Nutrition of Vinayaka Mission Hospital, Karaikal, Puducherry. After 37 newly diagnosed male patients of Stage I Essential hypertension with no other risk factors (Classification based on the European Society of Hypertension Guidelines, 20038) of age between 34 to 42 years and having body mass index above 28 are selected screening them with help of Physicians for the exclusion criteria like known food allergy to nuts, familial hypercholesterolemia ; diabetes mellitus, secondary hypertension, liver, kidney, thyroid or other endocrine diseases as assessed by medical history, a complete physical examination and laboratory tests; no intake in the previous 
8 weeks of medications known to affectlipid metabolism including hypolipidaemic agents. All the patients are provided with information sheets in the vernacular language and informed consent is obtained from them.

STUDY DESIGN: The detailed diet history of the each subjects were obtained with the help of dietitian. A crossover feeding design was used. Patients were assigned the two type of diet in which one is control and other is study diet incorporated with walnut. Individually all the patients were given in detail written and oral instructions of the diet to be followed. The patients followed control diet for four weeks and then the walnut diet for six weeks as lipoprotein changes due to dietary intervention stabilize in less than 4 weeks ${ }^{20}$. We did notincorporate a washout period between diets as Sabaté and colleagues ${ }^{2}$ did not observe a carryover effect in their crossoverfeeding study using walnut. All measurements like anthropometry, blood pressure and lipid profile are done at the start, after completion of intake of control diet and walnut diet.

DIETS: The experimental diets were individually prescribed and were based on estimated energy requirements. Because participants ate on their own, detailed dietary information was provided to them and, if appropriate, to their partners. Diets were calculated in increments of $200 \mathrm{kcal}$ to cover the range from 1600 to $2200 \mathrm{kcal}$. The control diet was local diet and was composed of natural foodstuffs. Red meat and eggs were limited, vegetable products and fish were emphasized and no nuts were allowed. The walnut diet was similar to the control diet, but walnuts partially replaced sunflower oil and other fatty foods. Prepackaged daily allowances of raw, shelled walnuts were provided daily in amounts varying from $30 \mathrm{~g}$ to $45 \mathrm{~g}$ (the equivalent of 6 to 8 walnuts), according to the participants' total energy intake. Walnuts were consumed as snacks or with meals in the form of salads. In the study diet, walnuts contributed approximately $18 \%$ of the total energy and $33 \%$ of the total energy from fat. Adherence to the control and walnut diets was carefully monitored. The patients were called intermittently for assessing the strict adherence to the prescribed diet and schedule. They were asked to maintain a diary for recording the daily diet they are having. We defined noncompliance as at least $20 \%$ deviation from dietary instructions regarding walnut or nutrient intake.

MEASUREMENTS: BLOOD PRESSURE MEASUREMENTS: For blood pressure measurement European Society of Hypertension guidelines are followed Blood pressure was measured by a standard mercury sphygmomanometer (Industrial Electronic and Allied Products, Pune, India). All measurements are taken in the sitting position. The same physician measured the blood pressure using the same instrument for all the subjects.

LABORATORY MEASUREMENTS: Venous blood was obtained after 14 hours of overnight fast, and serum and EDTA plasma were collected and processed immediately. Total cholesterol (TC), high Density Lipoprotein- Cholesterol (HDL-C) and Triglycerides (TG) in plasma were measured by enzymatic methods using auto analyzer (De Behring Dimension RXL Max with HM) in the central clinical laboratory. Low-Density Lipoprotein- Cholesterol (LDL-C) was calculated by Friedewald's ${ }^{10}$ formula.

STATISTICAL ANALYSIS: The two measurements obtained at baseline and at the end of each dietary period were averaged. Means and SDs are presented for each measurement. With 
methods described by Fleiss ${ }^{11}$, two-tailed $t$-tests and the percentage difference were used to compare changes in outcome variables in response to dietary treatment at the end of control diet ( 4 weeks) and at the end of consumption of walnut diet ( 6 weeks) in the crossover design. For the statistical analysis was done with the help of Microsoft Office Excel 2007.

RESULTS: PATIENT CHARACTERISTICS: Of the 38 eligible patients, 4 left the study before randomization for various reasons. 7 patients were excluded from the study due to various reasons and only 27 remained in the study till end.

DIETARY COMPLIANCE: On assessment nutrient content of the self-reported diets was close to that of the planned diets. According to participants' reports and to recounts of empty packages, compliance with walnutingestion was 100\%. 3 patients reported abdominal discomfort and bloating sensation and left the study in between. 5 complained of loose stools but were compliant with the study.

CHANGES IN THE LIPID PROFILE (TABLE I): The serum lipid profile at baseline and at the end of each dietary period as well as the differences of effect between dietary interventions is presented in Table I. No carryover effect was seen between the periods. The mean total cholesterol level decreased by 9.64\%, LDL cholesterol decreased by 13.64\%, HDL/LDL ratio decreased by 28.94 which is statistically more significant and increase HDL cholesterol (p value 0.02 ) ) is significant due to walnut diet as compared to control diet.

CHANGES IN BLOOD PRESSURE (TABLE II): Due to walnut diet as compared to control diet the systolic blood pressure is reduced by $11.57 \%$ (P value $<0.001$ ) and diastolic blood pressure reduced by $9.87 \%$ (P value $<0.001)$.

DISCUSSION: In this 10-week crossover dietary intervention trial in 27 stage I hypertensive men, we found that substituting walnuts for approximately $33 \%$ of the energy from fat decreased total cholesterol and LDLcholesterol levels and increased HDL cholesterol and lowered the HDL/LDL ratio significantly. Our findings are consistent with those of an earlier study in normal young men. Inclusion of walnut in the diet of patients decreased systolic and diastolic blood pressure significantly and it is consistent with the previous studies conducted to show its effect on blood pressure ${ }^{2}$. These complex changes are consistent in the view that essential hypertension is associated with an abnormal level of antioxidant status compared to normal response to oxidative stress or both ${ }^{12}$. An increase in production of Reactive oxygen species (ROS) like superoxide anion and hydrogen peroxide, reduction of nitric oxide synthesis, and a decrease in bioavailability of antioxidants have been demonstrated in human hypertension ${ }^{13}$. Some findings demonstrate a strong association between blood pressure and some oxidative stress-related parameters and an abnormal level of antioxidant status as compared to normal response in development of the pathophysiology of essential hypertension ${ }^{14}$. Walnut compounds like vitamin E (as $\gamma$-tocopherol), melatonin, and several non-flavonoid polyphenols (e.g., ellagic acid monomers and polymeric ellagitannins) are known to have the antioxidant capacity. Walnut consumption increases the blood Melatonin and polyphenol correlates with an increased antioxidative capacity of serum which scavenges the free radicals and increases the bio-availability of nitric oxide (NO) leads to increase in the vasodilatation which decreases blood pressure ${ }^{15}$. An animal study indicates (n-3) 
polyunsaturated fatty acids (PUFA)-deficient diet lessens the melatonin rhythm, weakens endogenous functioning of the circadian clock, and plays a role in nocturnal sleep disturbances, increases sympathetic nervous system activity and leads to higher setting of arterial blood pressure $^{16}$. A study suggests melatonin is present in walnuts and when eaten increase blood melatonin concentrations ${ }^{17}$. Walnut rich in $\mathrm{n}-3$ pufa and melatonin solves both problems of sleep disturbance and high arterial blood pressure and betters circadian rhythm of blood pressure which involves night time dip in the blood pressure. Omega 3 fatty acids are also known to enhance parasympathetic activity and to increase the secretion of anti-inflammatory cytokines as well as acetylcholine in the hippocampus and helps to decrease the blood pressure and autonomic imbalance in patient of essential hypertension ${ }^{18.19}$. Walnut intake improves endothelial function by virtue of its anti-inflammatory potential of polyphenolic-rich walnut extracts and its abundant component ellagic acid on endothelial cells.

CONCLUSION: Supplementation walnut in the daily diet of young essential hypertensive patients results in significant improvement of the lipid profile and reduction in the blood pressure.

\section{REFERENCES:}

1 http://www.nal.usda.gov/fnic/foodcomp/cgi-bin/list_nut_edit.pl

2 Sabaté J, Fraser GE, Burke K, Knutsen SF, Bennett H, Lindsted KD. Effects of Walnuts on Serum Lipid Levels and Blood Pressure in Normal Men. N Engl J Med. 1993 Mar 4;328(9):603-7.

3 Daniel Zambón, MD; Joan Sabaté, MD, DrPH; Sonia Muñoz, PhD; Betina Campero, RD;Elena Casals, MD; Manuel Merlos, PhD; Juan C. Laguna, PhD; and Emilio Ros, MD. Substituting Walnuts for Monounsaturated Fat Improves the Serum Lipid Profile of hypercholesterolemic Men and Women. Ann Intern Med. 2000 Apr 4;132(7):538-46.

4 Iwamoto M, Imaizumi K, Sato M, Hirooka Y, Sakai K, Takeshita A, Kono M. Serum lipid profiles in Japanese women and men during consumption of walnuts. Eur J Clin Nutr. 2002 Jul;56(7):629-37.

5 Zibaeenezhad MJ, Rezaiezadeh M, Mowla A, Ayatollahi SM, Panjehshahin MR. Antihypertriglyceridemic effect of walnut oil. Angiology. 2003 Jul-Aug;54(4):411-4.

6 Iwamoto M, Imaizumi K, Sato M, Hirooka Y, Sakai K, Takeshita A, Kono M. Serum lipid profiles in Japanese women and men during consumption of walnuts. Eur J Clin Nutr. 2002 Jul;56(7):629-37.

7 Strazzullo P, Ferro-Luzzi A, Siani A, Scaccini C, Sette S, Catasta G,Mancini M. Changing the Mediterranean diet: effects on blood pressure. J Hypertens. 1986 Aug;4(4):407-12. (Medline)

8 Summary of the 2007 European Society of Hypertension (ESH) and European Society of Cardiology (ESC) Guidelines for the Management of Arterial Hypertension.

9 Kris-Etherton PM, Dietschy J. Design criteria for studies examining individual fatty acid effects on cardiovascular disease risk factors: human and animal studies. Am J Clin Nutr. 1997; 65(Suppl):1590S-6S.

10 Friedewald WT, Levy RI, Fredrickson DS. Estimation of the concentration of low-density lipoprotein cholesterol in plasma, without use of the preparative ultracentrifuge. Clin Chem 1972;18:499-502.

11 Fleiss JL. The Design and Analysis of Clinical Experiments. New York: J Wiley; 1986. 
12 Kashyap MK, Yadav V, Sherawat BS, Jain S, Kumari S, Khullar M, Sharma PC, Nath R. Different antioxidants status, total antioxidant power and free radicals in essential hypertension.Mol Cell Biochem. 2005 Sep;277(1-2):89-99.

13 Saito Y, Nakamura T, Kurabayashi M. Oxidative stress and mild hypertension. Nippon Rinsho. 2008 Aug;66(8):1525-9.

14 Rodrigo R, Prat H, Passalacqua W, Araya J, Guichard C, Bächler JP. Relationship between oxidative stress and essential hypertension. Hypertens Res. 2007 Dec;30(12):1159-67.

15 Torabian S, Haddad E, Rajaram S, Banta J, Sabaté J. Acute effect of nut consumption on plasma total polyphenols, antioxidant capacity and lipid peroxidation. J Hum Nutr Diet. 2009 Feb;22(1):64-71.

16 Lavialle M, Champeil-Potokar G, Alessandri JM, Balasse L, Guesnet P, Papillon C, Pévet P, Vancassel S, Vivien-Roels B, Denis I. An (n-3) polyunsaturated fatty acid-deficient diet disturbs daily locomotor activity, melatonin rhythm, and striatal dopamine in Syrian hamsters. Biomed Pharmacother. 2004 Oct; 58 Suppl 1:S56-68.

17 Reiter RJ, Manchester LC, Tan DX. Melatonin in walnuts: influence on levels of melatonin and total antioxidant capacity of blood.Nutrition. 2005 Sep;21(9):920-4.

18 Singh RB, Pella D, Mechirova V, Otsuka K. Can brain dysfunction be a predisposing factor for metabolic syndrome? Biomed Pharmacother. 2004 Oct;58 Suppl 1:S56-68.

19 Maser RE, Lenhard MJ. An overview of the effect of weight loss on cardiovascular autonomic function.Curr Diabetes Rev. 2007 Aug;3(3):204-11.

20 Steinberg D, Parthasarathy S, Carew TE, Khoo JC, Witztum JL. Beyond cholesterol. Modifications of low-density lipoprotein that increase its atherogenicity. N Engl J Med. 1989; 320:915-24.

Table 1: Change in the lipid Profile

\begin{tabular}{|c|c|c|c|c|c|c|}
\hline $\begin{array}{l}\text { Sr. } \\
\text { No }\end{array}$ & Variable & $\begin{array}{c}\text { Start } \\
0 \text { weeks } \\
\text { Mean } \pm \text { SD }\end{array}$ & $\begin{array}{c}\text { After Control } \\
\text { Diet } \\
4 \text { Weeks } \\
\text { Mean } \pm \text { SD }\end{array}$ & $\begin{array}{c}\text { After Walnut } \\
\text { Diet } \\
6 \text { Weeks } \\
\text { Mean } \pm \text { SD }\end{array}$ & $\begin{array}{l}\text { Treatment } \\
\text { Effect } \\
\text { Percentage } \\
\text { Change }\end{array}$ & $P$ value \\
\hline 1 & $\begin{array}{c}\text { Total } \\
\text { Cholesterol }\end{array}$ & $\begin{array}{c}\text { 193.9 SD } \pm \\
37.2\end{array}$ & $\begin{array}{c}191.9 \mathrm{SD} \pm \\
38.2\end{array}$ & $\begin{array}{c}\text { 173.4 SD } \pm \\
14.3\end{array}$ & -9.64 & $<0.01$ significant \\
\hline 2 & Triglycerides & $\begin{array}{c}\text { 164.14 SD } \pm \\
\quad 63.9\end{array}$ & $\begin{array}{c}160.3 \mathrm{SD} \pm \\
67.4\end{array}$ & $\begin{array}{c}139.12 \text { SD } \pm \\
36.9\end{array}$ & -13.21 & $<0.01$ Significant \\
\hline 3 & $\begin{array}{c}\text { HDL- } \\
\text { cholesterol }\end{array}$ & $\begin{array}{c}45.36 \mathrm{SD} \pm \\
4.83\end{array}$ & $\begin{array}{c}43.30 \mathrm{SD} \pm \\
\quad 4.05\end{array}$ & $\begin{array}{c}48.67 \mathrm{SD} \pm \\
3.02\end{array}$ & -12.4 & 0.02 significant \\
\hline 4 & $\begin{array}{c}\text { LDL- } \\
\text { Cholesterol }\end{array}$ & $\begin{array}{c}110.89 \mathrm{SD} \\
\pm 22.98\end{array}$ & $\begin{array}{c}\text { 113.89SD } \pm \\
27.28\end{array}$ & $\begin{array}{c}98.35 \mathrm{SD} \pm \\
10.38\end{array}$ & -13.64 & $<0.01$ significant \\
\hline 6 & HDL/LDL ratio & 0.41 & 0.38 & 0.49 & -28.94 & $\begin{array}{c}<0.001 \text { Highly } \\
\text { Significant }\end{array}$ \\
\hline \multicolumn{7}{|c|}{ All Values in mg /dl Mean \pm SD } \\
\hline
\end{tabular}


Table II: Changes in Blood pressure

\begin{tabular}{|c|c|c|c|c|c|c|} 
Sr. & Parameter & $\begin{array}{c}\text { Before start } \\
\text { of the study } \\
\text { Mean } \pm \text { SD }\end{array}$ & $\begin{array}{c}\text { After control } \\
\text { Diet (4weeks) } \\
\text { Mean } \pm \text { SD }\end{array}$ & $\begin{array}{c}\text { After walnut } \\
\text { Diet (6 weeks) } \\
\text { Mean } \pm \text { SD }\end{array}$ & $\begin{array}{c}\text { Treatment } \\
\text { Change } \\
\text { in \% }\end{array}$ & P value \\
\hline 1 & $\begin{array}{c}\text { Systolic Blood } \\
\text { pressure }\end{array}$ & $\begin{array}{c}148.61 \text { SD } \\
9.89\end{array}$ & $\begin{array}{c}147.61 \\
\text { SD } \pm 7.89\end{array}$ & 130.53 SD 8.09 & $-11.57 \%$ & $\begin{array}{c}<0.001 \text { Highly } \\
\text { Significant }\end{array}$ \\
\hline 2 & $\begin{array}{c}\text { Diastolic Blood } \\
\text { pressure }\end{array}$ & $\begin{array}{c}94.48 \mathrm{SD} \\
4.16\end{array}$ & $\begin{array}{c}95.76 \\
\mathrm{SD} \pm 5.16\end{array}$ & $\begin{array}{c}86.3 \\
\mathrm{SD} \pm 5.32\end{array}$ & $-9.87 \%$ & $\begin{array}{c}<0.001 \text { Highly } \\
\text { Significant }\end{array}$ \\
\hline
\end{tabular}

